\title{
APPOINTMENT OF NON-RESIDENT ADMINISTRATORS TO CREATE FEDERAL DIVERSITY JURISDICTION*
}

Is recent years, attorneys for the estates of decedents and persons under disability have made increasing use of the appointment of non-resident administrators as a means of obtaining federal diversity jurisdiction. It has been estimated, for example, that such cases comprise 20.5 per cent of the total diversity suits brought in the Eastern District of Pennsylvania. ${ }^{1}$ Usually the non-resident administrator has no relationship whatsoever to the deceased or his heirs. In most states all that need be done to appoint a new administrator is to have the original administrator resign and then to petition the probate court for certification of the chosen successor, ${ }^{2}$ a certification which is often automatic. And an attorney for an estate will often wait until. the estate is completely probated, except for the prosecution of the particular cause of action, before replacing the administrator with a non-resident successor. ${ }^{3}$

Administrators invoking diversity jurisdiction rely on Rule 17 (a) ${ }^{4}$ of the Federal Rules of Civil Procedure. With one exception, ${ }^{5}$ that rule confers on personal representatives the status of real party in interest. This means of obtaining federal jurisdiction is successful, however, only if the appointment of the non-resident administrator does not come within the terms of Section 1359 of the Judicial Code, a provision designed to control the manufacturing of diversity jurisdiction. That statute requires the dismissal of any action in which the parties have been "improperly or collusively made or joined" for purposes of obtaining federal jurisdiction. ${ }^{6}$ To date, attorneys have been al-

*Lang v. Elm City Constr. Co., 324 F.2d 235 (2d Cir. 1963), affirming 217 F. Supp. 873 (D. Conn. 1963).

1. American Law Institute, Study of The Diviston of Jurisdiction Between State and Feneral Courts 122-23 (Tent. Draft No. 1, 1963).

As a question of first impression, it would seem that courts should bar jurisdiction for such cases in which the appointment may be viewed as nothing but subterfuge and brings disrepute on the whole of diversity jurisdiction. Although recent proposals to prohibit this manipulation of administrators may evidence the validity of this reaction, court interpretation of the collusive jurisdiction statute has been more lenient. For two of the recent restrictive proposals see H.R. 2832 88th Cong., 1st Sess. (1963), printed at 109 Cong. Rec. 1108 (daily ed. Jan. 28, 1963) ; Amertcan Law Institute, Study of The Division of Jurisdiction Between State and Federal. Courts (Tent. Draft No. 1, 1963).

2. See 33 C.J.S. Executors and Administrators, $\S 82$ (1942).

3. See, e.g., Fike Estate, 80 Pa. D. \& C. 322, 323 (Orphans' Ct. 1951).

4. FED. R. CIv. P. 17(a) provides in part:

Real Party in Interest. Every action shall be prosecuted in the name of the real party in interest; but an executor, administrator, guardian, trustee of an express trust ... may sue in his own name without joining with him the party for whose benefit the action is brought....

5. See note 55 infra and accompanying text.

6. 28 U.S.C. $\$ 1359$ (1958) provides:

Parties collusively joined or made. A district court shall not have jurisdiction of a civil action in which any party, by assignment or otherwise, has been improperly or collusively made or joined to invoke the jurisdiction of such court.

Section 1359 has evolved from the "assignee clause" in the original Judiciary Act of 1789, 1 Stat. 78. The purpose of that clause was "to prevent the manufacture of Federal 
most uniformly successful in convincing courts that the appointment of a nonresident administrator does not fall within the prohibition of Section 1359.7

Lang v. Elm City Constr. Co., ${ }^{8}$ is a typical instance. Decedent in Lang, a resident of Connecticut, was killed by a bulldozer owned by defendant. The intestate heirs, the original administratrix (decedent's mother) and defendant, were also citizens of Connecticut. After cleaning up the entire estate except for the outstanding wrongful death action, the administratrix resigned. Plaintiff Lang, a citizen of Pennsylvania, was immediately appointed successor administrator by the probate court and within the week brought suit in the federal district court on the wrongful death claim. The parties stipulated that the current administrator had no personal relationship with the decedent or any of the heirs, and that the primary motive for his appointment was the creation of diversity jurisdiction. ${ }^{9}$ Nevertheless, both the district court and the Court of Appeals for the Second Circuit held that this manufacture of diversity jurisdiction did not violate Section 1359 and refused to dismiss the suit. ${ }^{10}$

The lenient attitude manifested by the courts in Lang is by no means novel; the Third Circuit, in Corabi v. Auto Racing, Inc., ${ }^{11}$ had come to the same diversity jurisdiction." See Historical and Revision notes following 28 U.S.C.A. \& 1359 (1958); Sowell v. Federal Reserve Bank, 268 U.S. 449, 453 (1925). By Act of March 3,1875 , ch. $137, \S 5,18$ Stat. 470 , a provision was added directing circuit courts to dismiss any suit whenever it appears that "the parties have been improperly or collusively made or joined ... for the purpose of creating a case cognizable" in the federal court. The purpose of this provision was to give the federal courts clear "statutory authority and direction to dismiss an original action or remand a removed suit where federal jurisdiction has been manufactured." MOORE, ComMrentaRY oN tHE U.S. JUDICIAL Code 151 (1949). Section 1359 has been construed to re-enact the provisions of the Act of 1875 and its successor, Act of March 3,1911, ch. 231, § 24(1), 36 Stat. 1091, without any substantial change. Jaffe v. Philadelphia \& W.R.R., 180 F.2d 1010, 1012 n.4 (3d Cir. 1950). For the purposes of this note these predecessor statutes will be considered identical to $\S 1359$, and the cases interpreting these statutes deemed applicable to a consideration of $\$ 1359$.

7. Corabi v. Auto Racing, Inc., 264 F.2d 784, 788 n.10 (3d Cir. 1959), lists the previous cases which are considered to support the validity of jurisdiction manufactured through appointment of a non-resident administrator. The following later cases also support this practice: County of Todd v. Loegering, 297 F.2d 470 (8th Cir. 1961) ; Jamison v. Kammerer, 264 F.2d 789 (3d Cir.), cert. denied, 361 U.S. 813 (1959); Meehan v. Central R.R., 181 F. Supp. 594 (S.D.N.Y. 1960).

Only two cases have disapproved of this maneuver and held that $\S 1359$ precluded federal jurisdiction: Martineau v. City of St. Paul, 172 F.2d 777 (8th Cir. 1949)-apparently overruled by McCoy v. Blakely, 217 F.2d 227 (8th Cir. 1957); Cerri v. AkronPeople's Telephone Co., 219 Fed. 285 (N.D. Ohio 1914). Professor Moore cites Cerri with approval and states that "the real party in interest rule may not be manipulated for the purpose of founding jurisdiction." 3 MOORE, FEDERAL PRACTICE $\{17.05$, at 1320 (2d ed. 1963).

8. 324 F.2d 235 (2d. Cir. 1963), affirming 217 F. Supp. 873 (D. Conn. 1963). The Second Circuit approved in its entirety the District Court opinion of Judge Timbers.

9. $217 \mathrm{~F}$. Supp. at 87475.

10. 324 F.2d 235 (2d Cir. 1963).

11. 264 F.2d 784 (3d Cir. 1959).

The Corabi opinion appears to be the best-reasoned among the many cases upholding such manufactured jurisdiction (see note 7 supra) and has been cited with approval in 
conclusion on a similar state of facts. This attitude seems derived from a series of Supreme Court decisions interpreting Section 1359 in the corporate context. The most famous of these cases is Black \& White Taxicab \& Transfer Co. v. Brown \& Yellow Taxicab \& Transfer Co. ${ }^{12}$ where a Kentucky corporation desired to enter into a contract which Kentucky state courts would predictably hold invalid, but which would predictably be upheld by federal courts applying federal common law under the doctrine of Swift $v$. Tyson. ${ }^{13}$ Before contracting, the Kentucky corporation conveyed all its property to a newly created Tennessee corporation, whose stock, it must be assumed, was

every similar case since its decision. See, e.g., Lang: "while the decision of the Third Circuit in Corabi is not controlling on this Court, it is persuasive and will be followed, absent a decision on the question by the Supreme Court or the Second Circuit." 217 F. Supp. at 877. Similar approval of Corabi was voiced by the Second Circuit in affirming the District Court decision. 324 F.2d 235 (2d Cir. 1963). Before the Corabi decision, Jaffe v. Philadelphia \& W.R.R., 180 F.2d 1010 (3d Cir. 1950), was considered the chief case in point, not because of the court's reasoning, but merely because it stood for the proposition that the appointment of a non-resident administrator to gain federal jurisdiction was not precluded by $\$ 1359$. In fact, its reasoning has little merit. The court relied on the "real party in interest test" of Mecom v. Fitzsimmons Drilling Co., 284 U.S. 183 (1931), in which the Supreme Court upheld the destruction of diversity through the appointment of an administrator who was a citizen of defendant's state. $J a f f e^{\prime}$ 's reliance on Mecom involves a distortion of that holding, for it is difficult to invoke language from an opinion allowing the elimination of diversity in order to justify a decision allowing its creation, especially in light of the contrasting federal policies regarding the destruction and creation of diversity. As Professor Moore points out, while there is a federal policy against manipulation creating diversity, there is no policy against its destruction 3 MOore, Federal Practice đf 17.05, at 1320-21 (2d ed. 1963). See also Note, 96 U. PA. L. REv. 897 (1948). The Jaffe court further maintained that a federal court is precluded from inquiring into the motives and intentions behind plaintiff's appointment as administrator. The court justified this position 'with the argument that to inquire into what lies behind the appointment is to attack collaterally the decree of the probate court designating the administrator. However, a mere examination by the federal court into the circumstances of the appointment does not appear to constitute such an attack. A finding that the administrator could not sue in federal court would in no way impair the validity of the appointment itself or preclude the administrator from suing in the state courts. Even if the federal court's examination were to disclose that the administrator had secured his appointment by false pretenses, his capacity or right to sue in the state probate court would not be impaired. See generally American Car \& Foundry Co. v. Anderson, 211 Fed. 301 (8th Cir. 1914); and Fridley v. Farmers \& Mechanies Sav. Bank, 136 Minn. 333, 162 N.W. 454 (1917).

The reasoning behind $J a f f e$, then, would appear to be faulty and insufficient to justify the decision. The other non-resident administrator cases rely for the most part on either this reasoning in Jaffe or upon the test discussed in the text infra. Since Corabi appears to embody the best of the reasoning used to uphold such appointments, it will form the basis for this discussion of their propriety.

12. 276 U.S. 518 (1928). See also Southern Realty Inv. Co. v. Walker, 211 U.S. 603 (1909) ; Lehigh Mining \& Mfg. Co. v. Kelly, 160 U.S. 327 (1895); Morris v. Gilmer, 129 U.S. 315 (1889) ; Bradbury v. Dennis, 310 F.2d 73 (10th Cir. 1962), cert. denied, 372 U.S. 928 (1963) ; Sheehan v. Municipal Light \& Power Co., 151 F.2d 65 (2d Cir. 1945); Amalgamated Clothing Workers v. Curlee Clothing Co., 19 F.2d 439 (8th Cir. 1927) ; Hurst v. McNeil, 12 Fed. Cas. 1039 (No. 6936) (C.C. Pa. 1804).

13. 41 U.S. (16 Pet.) 1 (1842). See notes $36-38$ infra and accompanying text. 
held by the same stockholders. The Kentucky corporation dissolved itself immediately thereafter. The new Tennessee corporation then proceeded to negotiate the desired contract and, two months later, brought suit in the Kentucky District Court to enjoin defendant, a Kentucky corporation, from interfering with the recently acquired contract rights. The Supreme Court rejected the contention that the predecessor to Section 1359 was applicable and refused to dismiss the suit for want of jurisdiction. The corporation's motive, it said, was irrelevant; since the transfer to the Tennessee corporation was complete, and the corporation was a citizen of Tennessee, diversity jurisdiction could not be denied. ${ }^{14}$ The result in Black $\&$ White seemed a departure from the Supreme Court reading of the same section a few years earlier. In Miller \& Lux, Inc. v. East Side Canal \& Irrigation Co. ${ }^{15}$ a corporation went through a similar interstate ballet, and the Court held that diversity jurisdiction was unavailable. There is one salient factual distinction between the two cases: in Miller $\mathcal{E}$ L $L u x$ the original corporation rather than its stockholders held all the stock of the new corporation. The original corporation remained in existence, transacting its ordinary business, and transferring to the out-ofstate corporation only that property which was to be involved in the lawsuit. The Court found that the plaintiff corporation had violated Section 1359 and dismissed the suit for lack of jurisdiction. The failure to dissolve the original corporation and the ability of that corporation to compel a reconveyance of the proceeds of the suit from the plaintiff corporation without consideration indicated to the Court that the conveyance of the cause of action to the new corporation was not a permanent or "real" transaction. ${ }^{10}$ The reservation of the power to pull the proceeds immediately back into the original jurisdiction signaled a failure to detach the new entity sufficiently from the forum. The peculiarity of this distinction rests on the court's treatment of future behavior. The motive of the Tennessee corporation in Black $\mathcal{E}$. White was to be disregarded; but the potential action of the old Miller $\mathcal{E}$ Lux corporation seemed to be central to the Court's finding of a Section 1359 violation. ${ }^{17}$

Translating these cases into the context of estate administration, the Corabi

14. 276 U.S. at 524-25.

15. 211 U.S. 293 (1908). Lehigh Mining \& Mfg. Co. v. Kelly, 160 U.S. 327 (1895), has similar facts and is commonly cited with Miller $\mathcal{E}$ Lux as standing for the same principles.

16. 211 U.S. $300-04$.

17. This test has been utilized by other courts in differentiating between collusive and non-collusive attempts to create diversity. See, e.g., Tower Realty Co. v. City of East Detroit, 185 F.2d 590 (6th Cir. 1950) (remanded to district court for factual determination) ; Paper Makers Importing Co. v. City of Milwaukee, 165 F. Supp. 491 (E.D. Wis. 1958) ("complete and irrevocable transfer" held valid to create diversity).

In McDonald v. Smalley, 26 U.S. (1 Pet.) 620 (1828), land was sold to plaintiff for less than: its value because the vendor doubted that his title would be sustained in the state courts. Plaintiff, a resident of another state, sued the defendant for a conveyance in the federal court on the basis of diversity jurisdiction. The Court found good consideration and held the conveyance binding on both plaintiff and his vendor and effective to extinguish the resident vendor's title. In upholding the federal jurisdiction, the Court concluded 
court found the facts more like Black \& White than Miller $\mathcal{E}$ Lux. ${ }^{18}$ All formal ties were cut. The old administrator had resigned and the appointment of the successor administrator had been approved by the state probate court. No other objective action was available to make the transfer more permanent. Under Rule 17, the court was precluded from looking behind the administrator to determine whether the actual beneficiaries of the suit were citizens of the defendant's state. ${ }^{19}$ But by restricting itself to the severance of formal connections in cases involving appointment of non-resident administrators, the court validated all such attempts to obtain diversity jurisdiction. While the plaintiffs in Corabi had done everything they could to make the change in administrators permanent, it is equally true that they could have done no less and still have made an effective change. ${ }^{20}$ Black $\mathcal{E}$ White could have been distinguished in both Corabi and Lang on the ground that all business of the forum-state corporation had been transferred to the new corporation; in Miller $\mathcal{F} L u x$ the new corporation received only those rights necessary to enable it to prosecute the litigation. Seen from this perspective, cases like Corabi and Lang resemble Miller $\mathcal{E} L u x$, since all that is left for the out-of-state administrator is the prosecution of the diversity action. ${ }^{21}$

The permissive interpretation of Section 1359 seems unwise for reasons other than its use of precedent. An expansive view of diversity jurisdiction seems strangely at odds with the attitude of the Supreme Court toward federal question jurisdiction. Though there is no equivalent for Section 1359 in the federal question jurisdiction area, the Court has steadfastly refused to interpret that jurisdictional grant broadly. It will not entertain suits in which a federal question is raised by the anticipation of a defense, even where this question is clearly the sole issue of the case. ${ }^{22}$ It has been said that federal

that since plaintiff could not have maintained an action in debt for his money nor the vendor a suit for the land transferred, the transaction was real and permanent.

18. The court concluded that it could not "distinguish the facts of . . [Black \& Whitc] in any practical way from those of the case at bar." It stated that it would, however, have "consider[ed] the decision in ... Miller \& Lux as persuasive were it not for the latter decision" in Black \& White. 264 F.2d at 787.

19. Fen. R. Crv. P. 17(a).

20. All that need be done to replace an administrator is to have the probate court accept the resignation of the old administrator and approve the appointment of a successor. This has qualified the maneuver as real, irrevocable and complete, but it must be noted that these minimal actions are required for any change in administrators in order to comply with the probate laws, and might be viewed as having no more relation to the formal completeness of the break with the forum state than did the incorporation of the new non-resident company in Miller \& Lux.

21. In both Corabi and Lang the original administrator cleared up the entire estate except for the outstanding action for wrongful death. This cause of action was prosecuted by the successor non-resident administrator and constituted his sole contribution to, and connection with, the estate.

22. In Louisville \& N.R.R. v. Mottley, 211 U.S. 149 (1908), the Court raised the jurisdictional question on its own and dismissed the action, although it was clear that the issue would eventually be decided by a federal court. Indeed, the same case was back before the Court for a decision on the merits three years later, after the state court remedies had been exhausted. 219 U.S. 467 (1911). 
question jurisdiction cannot be enlarged by artful pleading, ${ }^{23}$ nor by improperly seeking equitable relief, ${ }^{24}$ nor by an action for declaratory judgment. ${ }^{26}$ In these cases, a court is dealing with the status of the legal issues, while in the manufactured diversity cases it is dealing with the unnatural status of the parties; the questions presented in federal question cases are particularly within the competency of the federal courts. If reluctance to take doubtful cases involving federal questions is soundly grounded, doubtful cases in diversity should be more readily shunned.

The analogy to problems in federal question jurisdiction indicates that the scope of Section 1359 cannot be determined, and the policies behind diversity jurisdiction carried out, by concentrating solely on the incident of change relating to the plaintiff's citizenship. The Supreme Court has shied away from motive in testing when collusion is present for Section 1359 purposes ; in cases like Corabi and Lang, where the factual indicia are so unrevealing, ${ }^{27}$ it may be necessary to inquire into motive to test whether diversity has been collusively manufactured.

The Supreme Court has never given a reason for its consistent refusal to consider party intent. One rationale, suggested by the Corabi court, rests on a literal reading of Section 1359: "[A] district court shall not have jurisdiction of a civil action in which any party ... has been improperly or collusively made or joined to invoke the jurisdiction of such court."28 Since the part of the statute beginning "to invoke" seems to impose a requirement that there be an intent to create diversity, it can be argued that the statutory phrase "improperly or collusively" must mean that something other than mere intent is required by Section 1359,29 namely "fictitious" and "sham" acts. At the level of word analysis it is difficult to quarrel with this suggestion. Such a statutory interpretation, however, may overlook the basic policies of the statute. ${ }^{30}$

23. Skelly Oil Co. v. Phillips Petroleum Co., 339 U.S. 667 (1950).

24. White v. Sparkill Realty Corp., 280 U.S. 500 (1930). See 2 Moore, FEderal Practice $\llbracket$ 2.07[3], at 404-05 (2d ed. 1962).

25. Public Service Comm'n v. Wycoff Co., 344 U.S. 237 (1952).

26. See Black \& White Taxicab \& Transfer Co. v. Brown \& Yellow Taxicab \& Transfer Co., 276 U.S. 518, 524 (1928) ; McDonald v. Smalley, 26 U.S. (1 Pet.) 620, 624 (1828). See also Cohan \& Tate, Mamufacturing Federal Diversity Jurisdiction by the Appointment of Representatives: Its Legality and Propriely, 1 VILL. L. Rev. 201, 209 (1956).

27. See note 20 supra and accompanying text.

28. 28 U.S.C. $\$ 1359$ (1958). See note 6 supra.

29. The court in Corabi made such an argument in its decision. 264 F.2d at 788. It does not appear, however, that this was the primary basis for the decision, since it was utilized merely as support for the conclusion otherwise reached by analysis of Black \& White.

30. In Lehigh Mining \& Mfg. Co. v. Kelly, 160 U.S. 327 (1895), the Court noted that the construction of the collusive jurisdiction statute is a practical rather than a mechanical matter, because if not so construed it "would become of no practical value, and the dockets of the Circuit Courts ... [would] be crowded with suits of which neither the framers of the Constitution nor Congress ever intended they should take cognizance." Id. at 343. See also Smith v. Sperling, 354 U.S. 91,97 (1957), in which the Court repeated the admonition that application of $\S 1359$ should be practical rather than mechanical. 
Though there is overabundant dispute on the issue, the principal policy basis for diversity jurisdiction is claimed to be the possibility that state courts will be biased against non-residents. ${ }^{31}$ If an individual completely severs his connection with one state and becomes a citizen of another, this bias justification could be said to apply to him regardless of his motive for changing citizenship. ${ }^{32}$ Thus, in Black $\mathcal{E}$ White plaintiff's appearance was entirely that of a Tennessee corporation, and was nearly certain to remain so. ${ }^{33}$ In Miller $\&$ Lux, on the other hand, the original corporation did not dissolve. ${ }^{34}$ The residual domestic quality presumably would have become known to the jury or judge, who would then, hypothetically, have had no reason (other than that provided them by the corporation's self-serving exercise) to vent their local prejudices.

Whatever strength it may have for diversity jurisdiction generally, however, the presumption of bias is a poor weapon for the defense of the suitor who has rendered himself a foreigner principally in order to obtain the benefits of that jurisdiction. The party who seeks to create diversity jurisdiction is not likely to do so because of fear that state tribunals will be prejudiced against him as a foreigner. He will have other reasons for his choice. If these reasons are ones the court should not honor, then, the lenient rule of Corabi and Lang should be abandoned in favor of a stricter test.

Although the implications of Erie R.R. v. Tompkins ${ }^{35}$ for Section 1359 were ignored in Corabi and Lang, Erie should provide the framework for

Mechanically giving the words "collusively" and "improperly" such literal significance would defeat the practical policy against manufactured jurisdiction and forum shopping embodied in both $\$ 1359$ and the Erie decision.

31. Although the grant of diversity jurisdiction to the federal courts has several explanations, this is the most widely accepted. 1 MOoRE, FEderal PRACTICE $\{0.60$ [8-4] at 636 (2d ed. 1960). See generally Phillips \& Christenson, The Historical and Legal Background of the Diversity Jurisdiction, 46 A.B.A.J. 959 (1960); Meador, A New Approach to Limiting Diversity Jurisdiction, 46 A.B.A.J. 383 (1960) ; Marbury, Why Shonld We Limit Federal Diversity Jurisdiction?, 46 A.B.A.J. 379 (1960); Doub, An Old Problem: The Federal Diversity Jurisdiction, 45 A.B.A.J. 1273 (1959); Wechsler, Federal Jurisdiction and the Revision of the Judicial Code, 13 Law \& Contemp. Prob. 216 (1948); Friendly, The Historic Basis of Diversity Jurisdiction, 41 Harv. L. Rev. 483 (1928). For a more complete statement of the policies often found for diversity jurisdiction, see Note, 73 YALE L.J. 850 (1964).

32. Such a rationale establishes a presumption of bias against a non-resident in state courts. Once it is determined that he is a citizen of another state, the court is precluded from looking behind that presumption in order to determine whether such bias is a real possibility. See, e.g., Baker v. Keck, 13 F. Supp. 486 (E.D. I11. 1936). In view of the many problems inherent in attempting to determine whether bias actually exists, such a presumption would appear reasonable.

33. Had the corporation re-incorporated in Kentucky, the contract it sought to validate by moving to Tennessee would have become invalid. Since the contract was unenforceable under state law, moving back into Kentucky, by giving the Kentucky courts jurisdiction, would only serve to resurrect the very problem which the corporation successfully avoided by leaving the state.

34. The Court found that the proceeds of the suit could, and probably would, be transferred back to the original corporation. 211 U.S. at 304.

35. 304 U.S. 64 (1938). 
examining these reasons. Cases like Black \& White and Miller $\&$ Lux were creatures of Swift $v$. Tyson, ${ }^{36}$ which Erie overruled. The Swift doctrine allowed federal courts sitting in a given state to apply substantive law which differed from that applied by the state courts. Therefore, a non-citizen plaintiff could determine whether a state or federal court should adjudicate a particular case on the basis of which court would apply law more favorable to his position. ${ }^{37}$ In diversity cases, the inevitable result was widespread federal-state "forum shopping" to choose the court with the more favorable substantive law. ${ }^{38}$ To a large extent, Erie was a reaction against such forum shopping..$^{39}$ And the "outcome-determinative" test enunciated in Guaranty Trust Co.v. York ${ }^{40}$ and other Erie progeny represents a further application of such a policy. These cases hold that in all diversity cases the outcome of the litigation in the federal court should be substantially the same as it would have been if tried in the state courts. ${ }^{41}$

Erie did not, of course, entirely obviate the need for Section 1359. The very fact that a dual system of courts exists means that there will be some

36. 41 U.S. (16 Pet.) 1 (1842). For discussion of Erie's ramifications, see 1 Moore, FeDERAI. Practice $\uparrow .304$ (2d ed. 1960) and articles cited therein.

37. See, e.g., Fellman; Ten Years of the Supreme Court: 1937-1947, 41 Am. PoL. Scr. Rev. 1142, 1150 (1947) ; Note, 13 St. JoHN's L. REv. 71, 75 (1938).

38. Frank, For Maintaining Diversity Jurisdiction, 73 YALE L.J. 7, 9 (1963) ; Snepp, The Law Applied in the Federal Courts, 13 LAw \& Contearp. Prob. 165, 167 (1948); Miller, Swift v. Tyson and Some Considerations of Philosophy in American Law, 11 Miss. L.J. 243, 251 (1939); Bowman, The Unconstitutionality of the Rule of Swift \%. Tyson, 18 B.U.L. REv. 659, 664-65 (1938); Note, 22 MrNN. L. REv. 885, 887 (1938).

39. Commentators have frequently mentioned the elimination of forum shopping in the federal system as an important policy basis for the Erie decision. See, e.g., Quigley, Congressional Repair of the Erie Derailment, 60 MicH. L. Rev. 1031, 1071 (1962); Gorrell \& Weed, Erie Railroad: Ten Years After, 9 OnIo St. L.J. 276, 284 (1948); Clark, State Law in the Federal Courts: The Brooding Omnipresence of Erie v. Tompkins, 55 Yale L.J. 267, 287, 294 (1946) ; Note, 30 MinN. L. Rev. 643, 645 (1946). See also Hart \& Wechsler, The Federal Courts and The Federal System 634 (1953).

40. 326 U.S. 99,109 (1945).

41. "In essence, the intent of that decision [Erie] was to insure that, in all cases where a federal court is exercising jurisdiction solely because of the diversity of citizenship of the parties, the outcome of the litigation in the federal court should be substantially the same . . . as it would be if tried in a State court." Guaranty Trust Co. v. York, 326 U.S. 99, 109 (1945). Recently the Supreme Court has stated that this outcomedeterminative test will fall if the state law to be applied conflicts with affirmative federal policy. Byrd v. Blue Ridge Rural Elec. Co-op, 356 U.S. 525 (1958). Allowing state probate practice to control the scope of diversity jurisdiction would be disruptive of federal jurisdictional practice. It might be argued, then, that the Lang and Corabi situation is disruptive of a federal policy of sound jurisdiction and should not be allowed.

For discussion of the outcome-determinative test, both past and present, see, e.g., Vestal, Erie R.R. v. Tompkins: A Projection, 48 Iowa L. Rev. 248 (1963); Note, 71 YaLE L.J. 344 (1961); Quigley, supra note 33; Kurland, Mr. Justice Frankfurter, The Supreme Court and the Erie Doctrine in Diversity Cases, 67 YALE L.J. 187 (1957); Note, 38 Geo. L.J. 115 (1949); 1A Moore, Federal. Practice โ 0.317[8], at 3540 (2d eđ. 1948). 
differences-in procedure, for example-between the two judicial systems, and counsel may well have sufficient preference for one system over the other to go to some trouble to gain entrance to it. An attorney may consider that federal calendars are less congested, federal judges superior, federal discovery rules more advantageous or federal juries likely to return higher verdicts. ${ }^{42}$ It may be impractical, impossible or undesirable to eliminate all these differences. Thus, parties will continue to be tempted to forum shop by manufacturing diversity jurisdiction. Correspondingly, the change accompanying Erie should bring with it a change in statutory interpretation. Where Section 1359 was once viewed as primarily aimed at preventing frauds on the court, ${ }^{43}$ its principal utility today should be the avoidance of undesirable forum shopping. ${ }^{44}$ Of course, a non-resident can be viewed as forum-shopping whenever he decides to bring a case in, or to remove to, a federal court. But the constitutional protections of diversity, however vague they may be, are legitimately his to claim. Where a party has manufactured diversity of citizenship, it is at best artificial to claim that he needs those protections; if his intent to forum shop is blatant and unmistakable, Section 1359 should be applied to deny him diversity jurisdiction.

Intent, however, is difficult to discern; abandonment of the Corabi test might be opposed on the ground that inquiry into motive is too subjective. In dealing with a motion to dismiss, moreover, the court would be required to resolve factual questions no less complex than questions likely to be presented at the final stage. Litigants would suffer substantial expense and delay. Yet these are problems of proof rather than substance, and they are problems which often may not arise. A firm rule presenting substantial impediments to diversity where collusion is suspected will dissuade many plaintiffs from attempting the barrier. More important, difficulties of proof will be reduced as the courts develop expertise in the administration of the rule. And inquiry into motive need not involve a full trial, with taking of oral

42. For an interesting analysis of the various factors which influence federal-state forum shopping, see Summers, Analysis of Factors That Influence Choice of Forum in Diversity Cases, 47 Iowa L. Rev. 933 (1962).

The courts are not blind to the fact that the prime motivation behind the choice of federal courts is often the belief that federal juries grant higher verdicts. See, e.g., Corabi v. Auto Racing, Inc., 264 F.2d 784, 788 (3d Cir. 1959). Attorney for plaintiff in Lang gave three reasons for preferring a federal court over that of a state:

... the enlightened rules of practice in the Federal Courts . . the uniform excellence of the judiciary . . . and, finally, because the jury selection system . . . has resulted consistently in the seating of intelligent jury panels.

217 F. Supp. at 875 n. 4 .

43. See, e.g., Lehigh Mining \& Mfg. Co. v. Kelly, 160 U.S. 327 (1895), where Justice Harlan concluded that the transfer of land "for the express purpose" of "creating a case for the Federal Court, must be regarded . . . as a fraud upon that court." Id. at 339. See also Amalgamated Clothing Workers v. Curlee Clothing Co., 19 F.2d 439, 440 (8th Cir. 1927).

44. See notes $35-41$ supra and accompanying text. 
evidence. Factors susceptible of summary presentation can be identified in the realities of plaintiffs' relations to the forum state and the cause of action.

Where plaintiffs seeking the haven of diversity are individuals suing in their own right, the factors traditionally used by courts to distinguish real from sham claims of citizenship seem to be well grounded in realities which tend to show predominant intent. These factors go to the question whether the individual has established citizenship in the new state; they most frequently include inquiry into the completeness of departure from the old state (Has furniture been moved? Have bank accounts been closed?) and the fullness of life in the new (Has plaintiff a job? A home? Has he registered? Voted? Or taken part in civic activities?). $\$ 5$ For an individual, formal and actual taking leave of a state may be indistinguishable; it may be postulated that the costs of breaking off relations to the degree required by the courts are so high that they are unlikely to be borne in a mere attempt to gain entrance to a federal court. Although the courts have consistently disclaimed that a primary intent to obtain diversity is a dispositive factor, the criteria they have adopted have the effect of making it most unlikely that a plaintiff with such an intent will succeed.

Similarly, objective criteria exist where a corporation is the suspect plaintiff, even though the formality of transfer of state of incorporation may signify little about the "real" citizenship of the corporation. Formalities meant little, for example, in Black $\mathcal{E}$ White; there, it must be assumed, the new corporation did business wholly in Kentucky and was owned and operated entirely by Kentuckians. On the other hand, a change of corporate citizenship, in the formal sense, will often reflect real changes. The process of dissolving a fairly large corporation is a tedious and expensive one not likely to be undertaken merely to obtain the tenuous benefits of federal jurisdiction in one suit. Such a change will often reflect changes in corporate structure or differential benefits under state law which the corporation is free to choose. Yet, where a corporation is closely held and predominantly active in the forum state, a sudden change in citizenship should not buy entrance to diversity jurisdiction, however complete the change in formal terms, absent some strong showing by plaintiff that his motives are not as they appear. ${ }^{46}$ Whether or not as a recognition of the policy against manufactured diversity, Congress has in fact acted to close federal courts to such corporations. In 1958 it passed a statute making corporations citizens of the state of their principal place of business as well as of the state of incorporation, thus limiting the occasions on which

45. See, e.g., Baker v. Keck, 13 F. Supp. 486 (E.D. Ill. 1936).

46. Such a contrary showing has been successful in the past. Thus, in Amalgamated Clothing Workers v. Curlee Clothing Co., 19 F.2d 439 (8th Cir. 1927), where it was shown that the defective re-incorporation (a power of recovery existed) was decided upon "without contemplation" of the impending litigation, that the "change was intended to be permanent and that federal jurisdiction was only one and probably a minor consideration for the change," the Court refused to dismiss plaintiff's claim under $\S 1359$. Id. at 440 . 
corporations have access to federal courts, ${ }^{47}$ and foreclosing the possibility that, on its particular facts, Black \& White could ever recur.

The indicia developed in the corporation cases fail completely when applied to cases where the appointment of personal representatives is the cause of the alleged collusive diversity. The only formality required to create diversity is the appointment itself, an act performed with particular ease. Jurisdiction can be manufactured with such facility that the possibilities for forum shopping are greatly increased. ${ }^{48}$ But the circumstances underlying the appointment may provide a court with many of the indicia by which it ordinarily determines intent. Thus, if, pursuant to a state wrongful death statute or survivors act calling for appointment of an administrator ad prosequendum, ${ }^{49}$ an administrator is appointed who is not a citizen of the state in which the estate is being probated, federal courts should be reluctant to grant federal jurisdiction to that administrator. His duties are temporary and related solely to the suit, for without the cause of action there would be no administrator, ${ }^{50}$ and the appointment of a non-resident for such temporary and singularly directed activities gives rise to an inference that the appointment was primarily for purposes of obtaining federal jurisdiction. In many cases, the circumstances may be even clearer. Typically, the administrator of an estate will have duties beyond the maintenance of the suit. It then becomes possible to scrutinize the allocation of duties and functions between forum and foreign administrators and to draw inferences from it about the motivation for appointments. In many instances, as was the case in Lang and Corabi, a resident administrator will perform the routine tasks of administering the estate and then resign in favor of a non-resident who will bring suit. An inference should arise that the appointment, as administrator, of a non-resident whose sole or primary duty was the bringing of suit was intended primarily to procure federal jurisdiction; if this inference of intent is not rebutted, jurisdiction should be denied under Section 1359.51 A further indicium might be the

47. 72 Stat. 415 (1958), amending 28 U.S.C. \$ 1332. See generally 1 MOORE, FEDERAI Pracrice If 0.60, at 640 (2d ed. 1948); Phillips \& Christenson, Should Corporations Be Regarded As Citizens Within the Diversity Jurisdiction Provisions?, 48 A.B.A.J. 435 (1962).

48. It is clear that the appointment of non-resident personal representatives to create diversity of citizenship is both easy to accomplish and frequently used. See note 1 supra and accompanying text. In the Lang and Corabi situation there is a clear danger of encouraging forum shopping if such manufacture of jurisdiction is allowed.

49. Many states require the appointment of an administrator ad prosequendum to sue on decedent's wrongful death action if the decedent dies intestate. He acts merely as a trustee, suing in his name for the benefit of those entitled to take under the statute granting the action for wrongful death. See, e.g., 2A N.J.S.A. 31-32 (1952).

50. Perhaps recognizing this, in New Jersey an administrator ad prosequendum is a nominal party, like a guardian ad litem. Loughney v. Thomas, 117 N.J.L. 169, 172, 187 Atl. 329, 331 (1936).

51. Plaintiff could rebut any inference of impropriety raised when an administrator resigns in favor of a non-resident by showing, for example, that the original administrator was unable to continue. See McCoy v. Blakely, 217 F.2d 227 (8th Cir. 1954), where 
fact that the foreign plaintiff is also the administrator for a number of similar suits in which he is claiming diversity jurisdiction. ${ }^{52}$ Such inferences could be rebutted, of course, by facts indicating a contrary intent. Thus, if the nonresident administrator is a relative or other person having a close business or personal relationship with the deceased or his heirs, and has administrative duties in addition to those involved in the litigation, the inference would be that the appointment was not primarily to gain diversity jurisdiction, but due rather to the relationship. ${ }^{53}$ Through a careful scrutiny of the circumstances in each case, then, a court should be able in most cases to determine the dominant motive in appointing a non-resident personal representative, and to apply Section 1359 accordingly.

A final objection to the adoption of a primary intent test should be considered. Rule 17 (b) has been interpreted to deny the status of real party in interest to a non-resident fiduciary where the law of the state in which the district court sits prohibits him from suing in the state courts. ${ }^{54}$ Thus, if a state is deeply concerned because its citizens are deprived of recourse to state courts by manufactured diversity jurisdiction, it can correct the situation it-

the first administrator testified that he could not manage the estate properly from a long distance, prompting the court to approve the appointment of his successor, a resident of the same state as decedent but a different state than that of the defendant and the first administrator.

52. See, e.g., Jamison v. Kemmerer, 264 F.2d 789 (3d Cir.), cert. denied, 361 U.S. 813 (1959), a companion suit to Corabi, where it was shown that the non-resident administrator in that case was also a non-resident administrator in 33 other diversity actions pending before the same district court.

53. Again, however, such an inference could be rebutted by the facts of the particular case, as in County of Todd v. Loegering, 297 F.2d 470, 473-74 (8th Cir. 1961), where decedent's mother, as administratrix, was unsuccessful in gaining federal jurisdiction, and thereupon resigned in favor of a non-resident sister of the decedent, prompting the court to note that the appointment of the sister was clearly for the purpose of gaining diversity jurisdiction.

54. FED. R. CIv. P. 17(b) :

Capacity to Sue or be Sued. The capacity of an individual, other than one acting in a representative capacity, to sue or be sued shall be determined by the law of his domicile. The capacity of a corporation to sue or be sued shall be determined by the law under which it was organized. In all other cases capacity to sue or be sued shall be determined by the law of the state in which the district court is held ....

Where the fiduciary is a nominal party under state law, the citizenship of the beneficiary and not that of the personal representative is looked to for purposes of diversity jurisdiction. Thames v. Mississippi, 117 F.2d 949 (5th Cir.), cert. denied, 314 U.S. 630 (1941). In Martineau v. Eastern Air Lines, Inc., 64 F. Supp. 235 (N.D. Ill. 1946), the district court appeared to narrow considerably the scope of rule 17 (b) by holding that a state statute, prohibiting suits by administrators for deaths occurring outside the state, related only to jurisdiction and, therefore, did not prevent diversity suits in the federal court. But Professor Moore points out that Angel v. Bullington, 330 U.S. 183 (1947) (right unenforceable in state court likewise unenforceable in federal court), should be taken to overrule Martineau. 3 Moore, Federal Practice If 17.19, at 1387 (2d ed. 1948). It thus appears that a non-resident administrator may not sue in a district court where by state law he is either a nominal party or lacks capacity to sue in the state courts. 
self. ${ }^{\text {vo }}$ But because the state can so act does not mean that federal courts should not. Important federal, as well as state, policies are infringed by manufactured jurisdiction and forum shopping, and to the extent federal policies may differ, their enforcement should not be left to the states. ${ }^{56}$

55. For categorization of state statutes restricting qualifications to sue of non-resident fiduciaries, see Note, 37 VA. L. REv. 1119 (1951).

56. In light of the present congestion of state court dockets, it may be that a state would look unfavorably upon any move which would restrict the present jurisdiction of the federal courts and, consequently, force more suits into its already crowded courts. Moreover, Professor Moore points out that if the federal courts are unwilling or unable to protect their own jurisdiction, it is unlikely that the states will shoulder their burden for them. 3 Moore, FederaI. Practice If 17.05, at 1322 (2d ed. 1948). 